\title{
Equilibrium and Kinetics Studies on Biosorption of Thallium (I) by Dead Biomass of Pseudomonas fluorescens
}

\author{
Jianyou Long*, Diyun Chen², Jianrong Xia ${ }^{1}$, Dinggui Luo ${ }^{1,3}$, \\ Bangfeng Zheng ${ }^{1}$, Yongheng Chen ${ }^{3}$ \\ ${ }^{1}$ School of Environmental Science and Engineering, Guangzhou University, Guangzhou, China, 510006 \\ ${ }^{2}$ Guangdong Provincial Key Laboratory of Radionuclide Pollution Control and Resources, \\ Guangzhou, China, 510006 \\ ${ }^{3}$ Innovation Center and Key Laboratory of Water Safety and Protection in the Pearl River Delta, \\ Ministry of Education, Guangzhou University, Guangzhou, China, 510006
}

Received: 4 November 2016

Accepted: 13 February 2017

\begin{abstract}
We investigated the biosorption characteristics of thallium (I) ions using dead biomass of Pseudomonas fluorescens strains as biosorbents. The biosorbents were characterized by Fourier transform infrared spectroscopy (FT-IR) and a scanning electron microscope (SEM). The effects of different environmental factors such as initial $\mathrm{Tl}$ concentration, initial solution $\mathrm{pH}$, biomass dosage, and contact time were evaluated. The maximum adsorption capacity was found to be $93.76 \mathrm{mg} / \mathrm{g}$ at an optimum initial $\mathrm{pH}$ of 5.0 , a contact time of $60 \mathrm{~min}$, a biomass of $0.5 \mathrm{~g} / \mathrm{L}$, and an initial $\mathrm{Tl}$ concentration of $50 \mu \mathrm{g} / \mathrm{mL}$. The biosorption process can be well defined by the Langmuir isotherm $\left(\mathrm{R}^{2}=0.9967\right)$. The biosorption kinetics were better described by the pseudo second-order model $\left(\mathrm{R}^{2}=0.9950\right)$ than the pseudo first-order one. The analysis of $(\mathrm{FT}-\mathrm{IR})$ indicates that the main functional groups responsible for adsorption of $\mathrm{Tl}$ (I) were hydroxyl, carboxyl, and amino groups. SEM analysis verifies an obvious surface morphology change of adsorbed biomass. The results presented in this study show that the Pseudomonas fluorescens could be an effective, low-cost, and environmentally friendly biosorbent for removing $\mathrm{Tl}$ (I) from aqueous solution.
\end{abstract}

Keywords: Thallium (I), biosorption characteristics, biomass, Pseudomonas fluorescens

\section{Introduction}

Heavy metals pollution has become a major concern among the most important world environmental issues that threaten the ecological environment and human

*e-mail: longjyou@gzhu.edu.cn health due to its toxicity and accumulation throughout the food chain [1]. Thallium is regarded as a lethally toxic metal that usually arises from mining wastewater, and it is produced as a by-product in the refining of iron, lead, zinc, and pyrite [2]. Even at low concentrations, after exposure, $\mathrm{Tl}$ can easily enter the human body and cause great chemical toxicity to the whole organism, such as lung insufficiency, bone degradation, liver and kidney 
damage, and inducing sarcoma and leukemia [3-4]. The removal of Tl-containing wastewater has generally been implemented using traditional methods [5-6] such as chemical ion exchange, filtration, reduction, oxidation, and precipitation [8]. However, these techniques have been proven to be cost-ineffective and time-consuming in their practical application. Hence, it is essential to explore other effective methods for removing $\mathrm{Tl}$ from wastewater.

Biosorption is a potential technology for utilizing the cost-effective biomass to remove heavy metals from wastewater due to their economical operation, ecofriendliness, good performance, and availability, and it has been verified for its adsorptive characteristic in many published reports [9]. Numerous microbial materials such as bacteria, fungi, algae, and yeast, both the living biomass and dead biomass can bind the heavy metals from wastewater [10]. Among the microorganisms, owing to functional groups on cell wall such as carboxyl, hydroxyl, amino, or sulfhydryl [11-12] for heavy metal ions binding, bacteria have exploited various resistance mechanisms to resist heavy metal stresses [13]. The use of dead biomass could prove superior to living biomass regarding less sensitivity to toxic metal ions and relatively simple executing conditions, plus no requirements for nutrients and culture media, and easy recovery and desorption after the biosorption process [14-15].

Different living and dead biomasses of bacteria have been used as adsorbents to remove heavy metals from the wastewater. [16] used a Cd-resistant Pseudomonas strain to remove Cd, while [17] used starfish and Pseudomonas putida strain for the adsorption of heavy metals and uranium from wastewater. However, there are no reports on the adsorption of $\mathrm{Tl}$ by Pseudomonas sp. from the wastewater. In this study, one resistant strain identified as Pseudomonas fluorescens, which showed a tolerance to thallium, was isolated and screened from the wastewater of Yunfu pyrite mine in southern China.

The aim of this paper was to investigate the potential application of Pseudomonas fluorescens as a substitutable adsorbent for the removal of thallium ions from aqueous solutions. The biosorption characteristics of different environmental parameters, including the effect of initial $\mathrm{Tl}$ concentration, initial solution $\mathrm{pH}$, biomass dosage, and contact time were evaluated. The isotherm and kinetic models of $\mathrm{Tl}$ adsorption were also constructed. In addition, the mechanism of biosorption was explored by Fourier transform infrared spectroscopy (FT-IR) and scanning electron microscope (SEM).

\section{Materials and Methods}

\section{Preparation of Dead Biomass}

Pseudomonas fluorescens was cultured in LB medium $(150 \mathrm{~mL})$ at $25^{\circ} \mathrm{C}$ in a $500 \mathrm{~mL}$ flask with shaking speed at $180 \mathrm{r} / \mathrm{min}$ for $24 \mathrm{~h}$. After fermentation, cultures were centrifuged at 10,000 r/min for $8 \mathrm{~min}$ and washed thrice with deionized water to collect the biomass. The dead biomass was acquired by heating at $121^{\circ} \mathrm{C}$ for $30 \mathrm{~min}$.

Structural Characterization by FT-IR Spectral and SEM

The biomass powder was mixed with dry $\mathrm{KBr}$ at a ratio of $1 \mathrm{mg} / 100 \mathrm{mg}$. The mixture was thoroughly incorporated and compressed into a small pellet [18]. The sample was analyzed using a Nicolet 380 spectrometer (USA) in the wavelength from $400-4,000 \mathrm{~cm}^{-1}$. The morphological properties of the strain Pseudomonas fluorescens before and after biosorption was investigated using a JEM-1230 analyzer (Japan).

\section{Sorption Isotherms}

The dynamic process of the solute adsorbed to the adsorbents depends on the biosorption equilibrium between solid and liquid phase, which could be described by the most typical adsorption isotherm models such as the Langmuir and Freundlich model. The Langmuir model simplifies the monolayer sorption, in which the solid surface is uniform and each adsorption can only be a molecular or atomic adsorption and with lateral interaction between the sorbed molecules. The Freundlich model describes the heterogenous adsorption and multilayer biosorption to the binding sites located on the surface of the adsorption equilibrium [19].

The Langmuir model [20] is described by the following equation:

$$
q_{e q}=\frac{q_{\max } b C_{e}}{1+b C_{e}}
$$

... where $q_{\mathrm{eq}}$ is the adsorbing capacity per gram of biomass at equilibrium $(\mathrm{mg} / \mathrm{g}), q_{\max }$ is the maximum adsorbent amount per unit weight of biomass, and $b$ is the adsorbent constant that concerns the binding force $(\mathrm{mg} / \mathrm{g})$. The Freundlich isotherm model [21] equation can be expressed by the form:

$$
q=K_{f} C_{e}^{1 / n}
$$

...where $q$ represents adsorption capacity for mass per unit mass of biomass at equilibrium; $C_{\mathrm{e}}$ represents the concentration of metal remaining in solution at equilibrium; and $k$ and $n$ are the Freundlich constants that help to describe the adsorption process.

\section{Batch Adsorption Experiments}

The batch adsorption of $\mathrm{Tl}$ experiments proceeded in an isothermal shaker. In order to determine the optimal initial concentration, $\mathrm{pH}$ range, biomass, and contact time we used $\mathrm{Tl}(\mathrm{I})$ solutions of $50 \mathrm{mg} / \mathrm{L}$. The effect of $\mathrm{pH}$ was investigated at the range of 2.0-8.0, biomass at the range of 1.0-6.0 g/L, concussion agitation speed was $180 \mathrm{r} / \mathrm{min}$ and temperature was $25^{\circ} \mathrm{C}$ was set for 
the biosorption experiments. In most of the experiments (except biomass variation study), $0.45 \mathrm{~g}$ of sorbent was added to $100 \mathrm{~mL}$ solution of $\mathrm{Tl}$. The biosorption capacity of $\mathrm{Tl}$ was calculated according to the following formula [22]:

$$
q=\frac{V\left(C_{0}-C_{e q}\right)}{M}
$$

...where $q$ means the biosorption capacity of heavy metal ions $(\mathrm{mg} / \mathrm{g}), C_{0}$ and $C_{\text {eq }}$ mean the initial and equilibrium metal concentrations in the solution $(\mathrm{mg} / \mathrm{L})$, respectively; $V$ is the volume of solution (L); and $M$ is the mass of adsorbent (g).

\section{Results and Discussion}

\section{FT-IR and SEM Analysis}

The FT-IR spectroscopy technique was applied to reveal which functional groups were responsible for the adsorption of Tl(I). The FT-IR spectra of before and after adsorption from the range of $400-4,000 \mathrm{~cm}^{-1}$ is presented in Fig. 1. It is demonstrated that functional groups on the cell wall were consistent with the adsorption bands. The broad bands at about $3,359 \mathrm{~cm}^{-1}$ represented the bonded $-\mathrm{NH}$ or $-\mathrm{OH}$ groups. The peaks near $2,928 \mathrm{~cm}^{-1}$ could be attributed to the $-\mathrm{CH}$ stretching [23]. The bands appearing at about $1,398 \mathrm{~cm}^{-1}$ were distributed carboxyl group $(-\mathrm{C}=\mathrm{O})$ stretching. The peaks observed at about $1,093 \mathrm{~cm}^{-1}$ were caused by $\mathrm{C}-\mathrm{O}$ stretching [24]. The peaks observed at about $727 \mathrm{~cm}^{-1}$ were assigned to the $-\mathrm{CH}$ stretching of the aromatic series.

The peak at $3,359 \mathrm{~cm}^{-1}$ was shifted to $3,376 \mathrm{~cm}^{-1}$ for $\mathrm{Tl}(\mathrm{I})$-loaded biomass. The peak of the $-\mathrm{CH}$ group was shifted from $2,928 \mathrm{~cm}^{-1}$ to $2,911 \mathrm{~cm}^{-1}$, the carboxyl

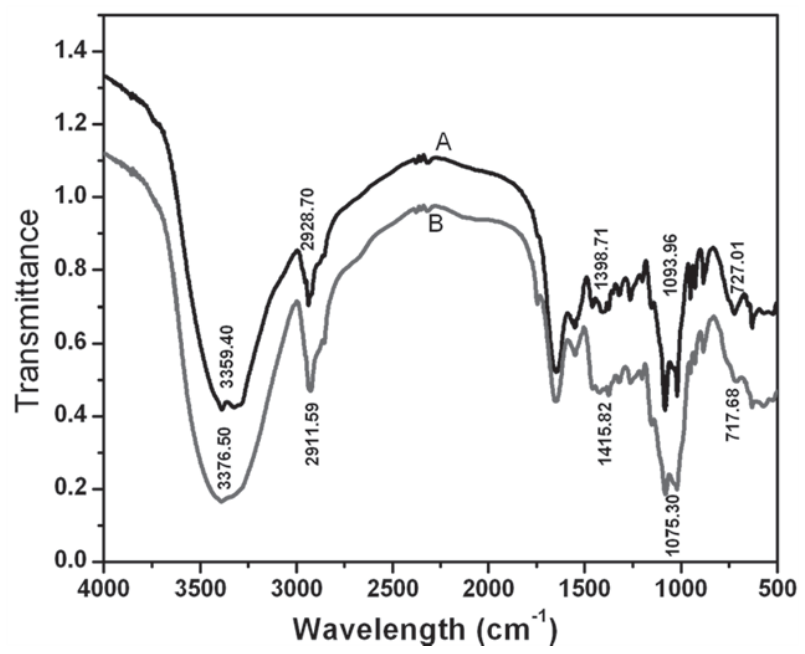

Fig. 1. FT-IR analysis for Pseudomonas fluorescens biomass (A) meaned strain before biosorption and (B) meaned strain after biosorption. peak was shifted from $1,398 \mathrm{~cm}^{-1}$ to $1,415 \mathrm{~cm}^{-1}$, the peak of - CO group was shifted from $1,093 \mathrm{~cm}^{-1}$ to $1,075 \mathrm{~cm}^{-1}$, and the stretching vibration at $727 \mathrm{~cm}^{-1}$ was shifted to $717 \mathrm{~cm}^{-1}$ after Tl(I) biosorption. These phenomena indicate that several functional groups have important roles in $\mathrm{Tl}(\mathrm{I})$ biosorption because of the components on the microbial cell wall and membrane [25-26]. These functional groups like carboxyl, hydroxyl, and amine actively participate in binding of metal ions by chemical interactions. The results favored the chemical process as ion-exchange between carboxyl, hydroxyl, and amine groups of the biomass, and the metal irons mainly participated in the adsorption of Tl(I) onto Pseudomonas fluorescens. Similar FT-IR results [27] for $\mathrm{Cd}$ and $\mathrm{Ni}$ adsorption onto bacterial biomass were reported, which are consistent with our findings.

The surface morphology of $\mathrm{Tl}$ explored by SEM images is shown in Fig. 2. Before biosorption (Fig. 2a), the adsorbent appeared as a smallish and porous surface structure. Nevertheless, after biosorption (Fig. 2b) the surface became rough. Such roughness of the surface might be because of the adsorption on thallium over the surface that makes the surface coarser than its original form. This finding is similar to that reported by Cui Pang et al. [28], in which biosorption of rubidium was conducted using rubidium-bearing bacteria.

\section{Effect of $\mathrm{pH}$ on Biosorption}

$\mathrm{pH}$ is a significant factor influencing the biosorption of heavy metal ions, which could affect the ionization of functional groups on cell walls and the precipitation of heavy metal in solution. The influence of $\mathrm{pH}$ on the biosorption of $\mathrm{Tl}(\mathrm{I})$ into Pseudomonas fluorescens was explored over the $\mathrm{pH}$ range 2.0 to 8.0 using $50 \mu \mathrm{g} / \mathrm{mL}$ initial $\mathrm{Tl}(\mathrm{I})$ concentration at normal temperature. The experimental data are exhibited in Fig. 3. Solutions of $0.5 \mathrm{M} \mathrm{HCl}$ and $\mathrm{NaOH}$ were used to adjust the $\mathrm{pH}$ of the $\mathrm{Tl}(\mathrm{I})$ solution. As can be seen from Fig. 3, the biosorption capacity of $\mathrm{Tl}(\mathrm{I})$ increased as the $\mathrm{pH}$ increased from 2.0 to 5.0 and reached a maximum at a $\mathrm{pH}$ of 5.0 , which was applied to all the subsequent experiments. The low adsorption capacity at lower $\mathrm{pH}$ values could be explained by that $\mathrm{H}^{+}$rather than $\mathrm{Tl}(\mathrm{I})$ in cells combined with negatively charged functional groups on the surface of binding sites. The gradual increase in solution $\mathrm{pH}$ will bring about the increase in the degree of ionization

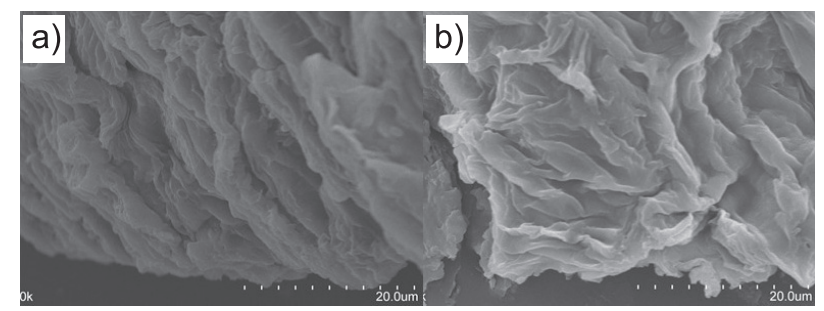

Fig. 2. Scanning electron microscope (SEM) analysis for Pseudomonas fluorescens biomass a) means before biosorption and b) means after biosorption. 


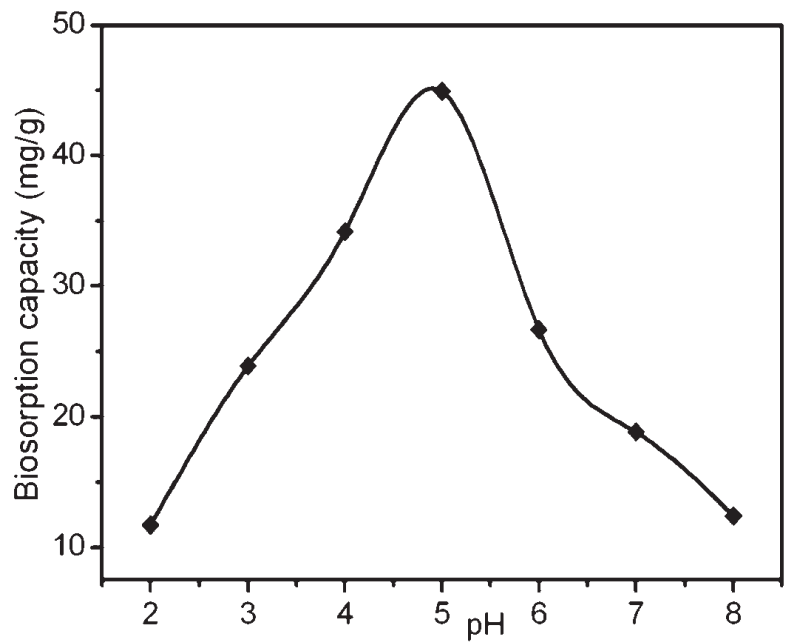

Fig. 3. Effect of $\mathrm{pH}$ on thallium(I) biosorption by Pseudomonas fluorescens (m: $0.45 \mathrm{~g}, \mathrm{~V}: 100 \mathrm{~mL}, \mathrm{Tl}: 50 \mu \mathrm{g} / \mathrm{mL}, 25^{\circ} \mathrm{C}$ ).

functional groups from the biomass surface, and therefore the degree of electrostatic interactions will also be strengthened. However, the adsorption capacity decreased as the solution $\mathrm{pH}$ continued to increase from the range 6.0 to 8.0 , which is probably due to the change in the form of heavy metals, as at higher $\mathrm{pH}$, the hydroxyl, bicarbonate ions in solution increased and competed binding sites with $\mathrm{Tl}(\mathrm{I})$, which ultimately lead to a reduction in adsorption capacity [29-30].

\section{Effect of Biomass on Biosorption}

The biomass of adsorbent could play an important role on biosorption. The influence of biomass quantity on biosorption is listed in Fig. 4. In this study, with the biomass from the range 0.1 to $0.6 \mathrm{~g} / \mathrm{L}$, the biosorption

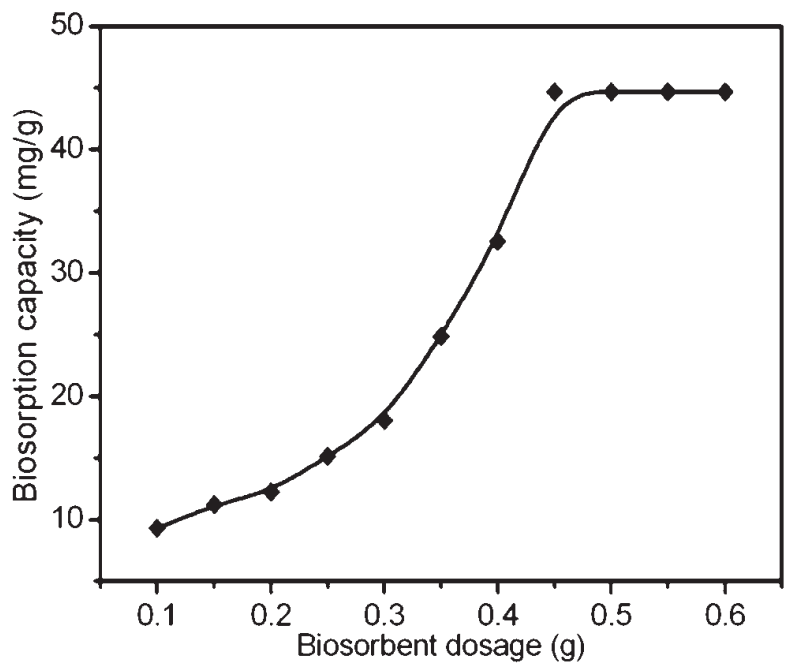

Fig. 4. Effect of biosorbent dosage on thallium(I) biosorption by Pseudomonas fluorescens (V: $100 \mathrm{~mL}$, Tl: $50 \mu \mathrm{g} / \mathrm{mL}$, time: $\left.60 \mathrm{~min}, 25^{\circ} \mathrm{C}\right)$. capacity was increased from 9.78 to $44.97 \mathrm{mg} / \mathrm{g}$, which can be explained by the fact that the increased biomass can provide large biosorption surface area and the available solute was sufficient to entirely cover the available exchangeable sites on strain surface and result in metal biosorption at high biomass concentration. The maximum biosorption capacity of Tl(I) was observed at $0.5 \mathrm{~g} / \mathrm{L}$. After reaching the maximum, there was no obvious increase in biosorption capacity, which is because the biomass reached saturation. Increased dosage can bring a surface effect to protect the active sites from being occupied by $\mathrm{Tl}(\mathrm{I})$, as documented by Nasrin Masoudzadeha et al. [31]. Meanwhile, no increase in biosorption as the result of the mutual interference between adsorption sites. This result is in line nicely with those published in other research papers [32].

\section{Effect of Contact Time on Biosorption}

Biosorption of $\mathrm{Tl}(\mathrm{I})$ by the Pseudomonas fluorescens strain as a function of time is described in Fig. 5. The biosorption capacity of $\mathrm{Tl}(\mathrm{I})$ for the dead biomass reached equilibrium within $60 \mathrm{~min}$. In the beginning, the biosorption capacity of biosorbents increased quickly owing to sufficient exploitable active adsorption sites on the biomass surface, and Tl(I) ions can easily interact with the binding sites. Afterward, these active binding sites were gradually occupied with $\mathrm{Tl}(\mathrm{I})$ ions and with gradual occupancy of these sites. After $60 \mathrm{~min}$, the biosorption capacity was almost constant due to the reduction of very few active sites being available in successful collisions of the Tl(I) ions on the surface of the strain Pseudomonas fluorescens, and due to a reduction in concentration gradient. Therefore, biosorption efficiency remains unchanged in the later stages [33]. Maximum biosorption capacity of $\mathrm{Tl}(\mathrm{I})$ by Pseudomonas fluorescens was found to be $44.91 \mathrm{mg} / \mathrm{g}$ under this condition in batch mode.

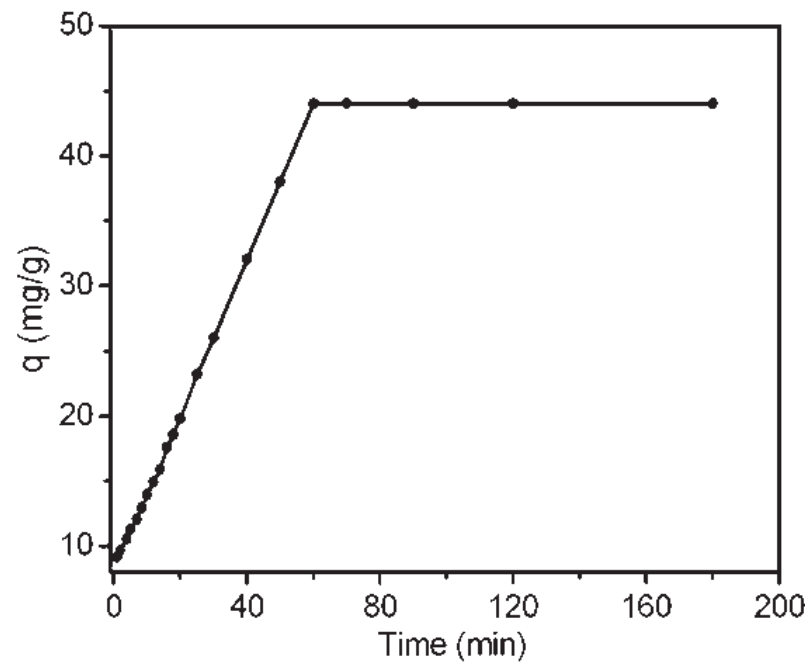

Fig. 5. Effect of contact time on thallium(I) biosorption by Pseudomonas fluorescens (m: 0.45g, V: $100 \mathrm{~mL}, \mathrm{Tl}: 50 \mu \mathrm{g} / \mathrm{mL}$, $\left.25^{\circ} \mathrm{C}\right)$. 


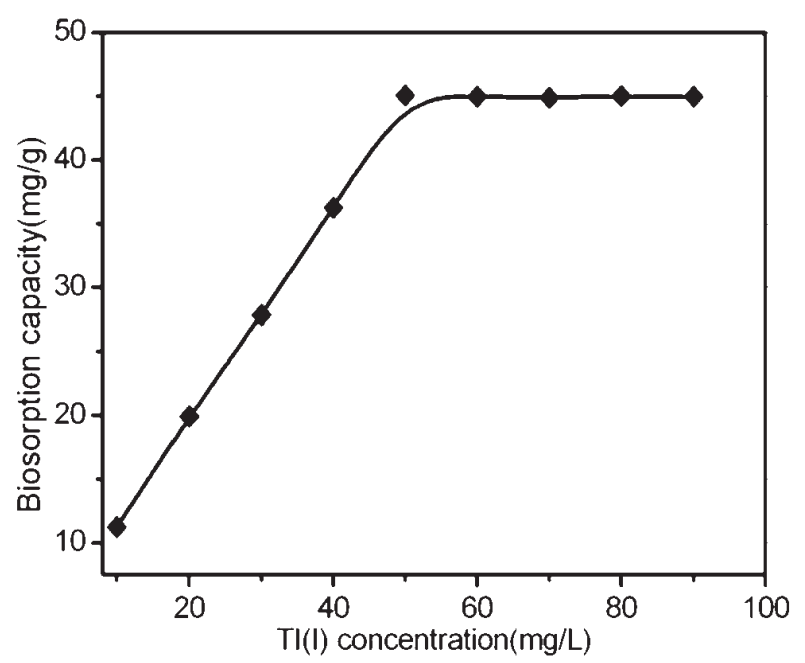

Fig. 6. Initial concentration of thallium (I) on biosorption by Pseudomonas fluorescens (m: $0.1 \mathrm{~g}, \mathrm{~V}: 100 \mathrm{~mL}, 25^{\circ} \mathrm{C}$ ).

\section{Influence of Initial $\mathrm{Tl}(\mathrm{I})$ Concentration on Biosorption}

The influence of initial $\mathrm{Tl}(\mathrm{I})$ concentration on biosorption by Pseudomonas fluorescens was investigated under varying initial $\mathrm{Tl}(\mathrm{I})$ concentrations ranging from 10 to $90 \mathrm{mg} / \mathrm{L}$ (Fig. 6). From 10 to $50 \mathrm{mg} / \mathrm{L}$ it is clear that the adsorption capacity of $\mathrm{Tl}(\mathrm{I})$ increased with the increasing amount of initial $\mathrm{Tl}(\mathrm{I})$ concentration, due to the fact that the ratio of the initial molecules of solute to the available surface area is low, and the initial concentration generates an important driving force to overcome all mass transfer resistance of $\mathrm{Tl}(\mathrm{I})$ between the aqueous and solid phases, and the maximum amount of $\mathrm{Tl}(\mathrm{I})$ adsorbed could reach $44.83 \mathrm{mg} / \mathrm{g}$ at an initial Tl(I) ion concentration of $50 \mathrm{mg} / \mathrm{L}$. When the initial $\mathrm{Tl}(\mathrm{I})$ ions concentration increased from 50 to $90 \mathrm{mg} / \mathrm{L}$, biosorption showed saturation at higher metal ion concentrations. Because cells offer a finite number of surface binding sites, similar results have been referred to by other authors according to Anindita et al. [34].

\section{Biosorption Isotherms}

Biosorption isotherms play an important role in the exploration and description of an adsorption model system. Thus, in our research the biosorption of $\mathrm{Tl}$ was evaluated by Langmuir and Freundlich isotherm models with $\mathrm{Tl}(\mathrm{I})$ ion concentration ranging from 10 to $90 \mathrm{mg} / \mathrm{L}$ at $25^{\circ} \mathrm{C}$ (Figs 7a-b). The Langmuir adsorption isotherm can fit the equilibrium data very well, with a high value of correlation coefficient $\left(\mathrm{R}^{2}=0.9967\right)$ and a maximum biosorptoin capacity of $93.76 \mathrm{mg} / \mathrm{g}$. Compared with the Langmuir isotherm, the Freundlich model described the adsorption process for less accuracy with a lower coefficient value of 0.9166 . This result implies that $\mathrm{Tl}(\mathrm{I})$ biosorption by the Pseudomonas fluorescens strain seems more likely to be a monolayer surface adsorption than heterogeneous adsorption.
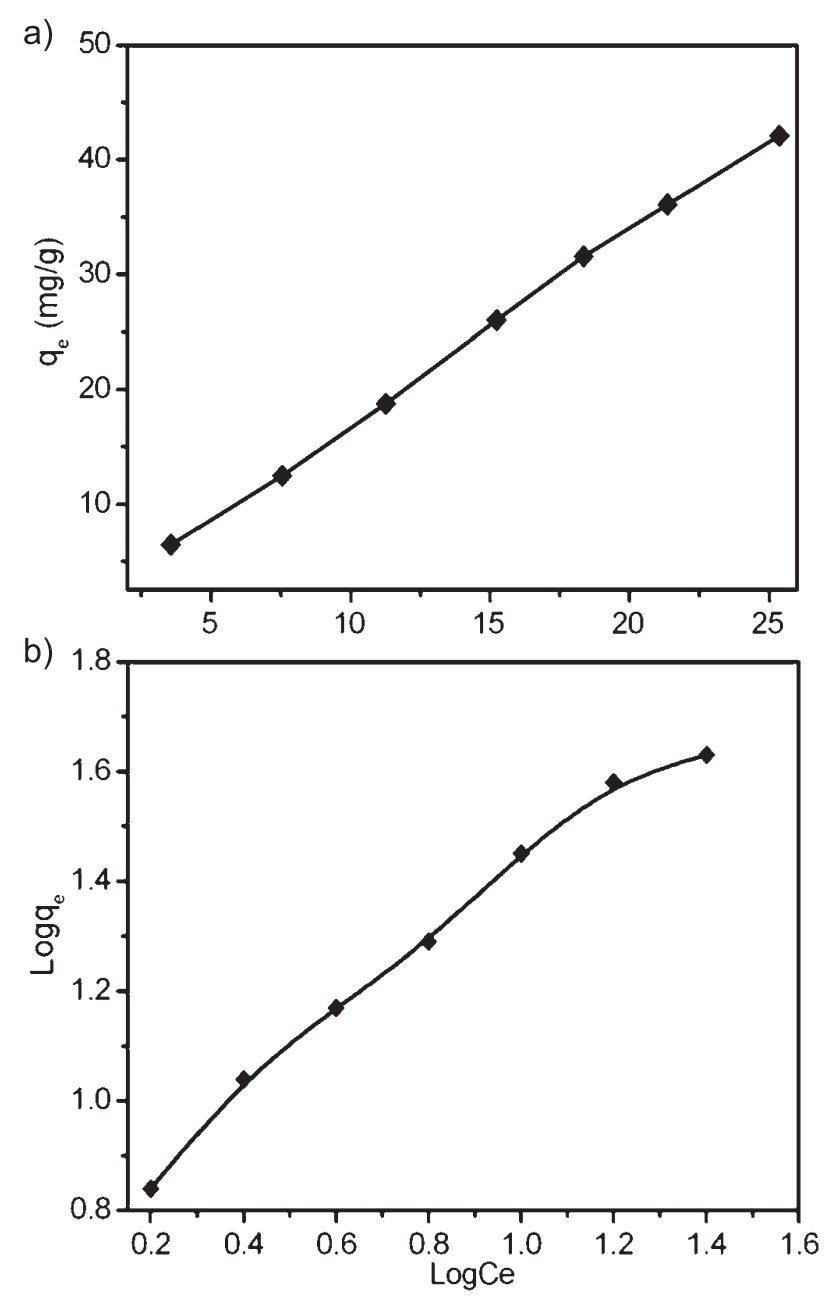

Fig. 7. a) Langmuir isotherm, b) Freundlich isotherm of sorption thallium on pseudomonas (m: 0.1g, V: $100 \mathrm{~mL}, \mathrm{Tl}: 50 \mu \mathrm{g} / \mathrm{mL}$, time: 60 min, $\mathrm{pH}: 5.0$ ).

\section{Biosorption Kinetic}

We used the explicit adsorption mechanisms of equilibrium processes such as functional groups transfer, chemical exchange, two kinetic models (including pseudo-first-order [35] and pseudo-second-order [36]) to depict the kinetic characteristics of $\mathrm{Tl}(\mathrm{I})$ on the strain of Pseudomonas fluorescens.

The pseudo first-order kinetic model in linear equation can be expressed as:

$$
\log \left(q_{e}-q_{t}\right)=\log q_{e}-K_{1} t / 2.303
$$

...where $q_{\mathrm{e}}$ is equilibrium adsorption $(\mathrm{mg} / \mathrm{g}), q_{\mathrm{t}}$ is the adsorption capacity at time $t(\mathrm{mg} / \mathrm{g})$ on the adsorbents, and $k_{1}$ means the equilibrium rate constant of pseudo firstorder adsorption $\left(\mathrm{min}^{-1}\right)$.

The pseudo second-order model is based on solid phase adsorption ability and is used to describe the whole biosorption process as shown by the following linear equation: 


$$
\frac{t}{q_{t}}=\frac{1}{k_{2} q_{e}^{2}}+\frac{t}{q_{e}}
$$

...where $k_{2}(\mathrm{~g} / \mathrm{mg} / \mathrm{h})$ is the second-order rate constant of adsorption process, $q_{\mathrm{t}}(\mathrm{mg} / \mathrm{g})$ is the quantity of biosorption at time ( $\mathrm{min}) t$, and $q_{\mathrm{e}}(\mathrm{mg} / \mathrm{g})$ is the quantity of biosorption equilibrium.

Using the above-mentioned formula, a linear equation with the vertical coordinates of $\log \left(q_{\mathrm{e}}-q_{\mathrm{t}}\right)$ vs. the horizontal coordinates of $t$ is plotted in Fig. 8. The $k_{l}, q_{\mathrm{e}}$, and the value of correlation coefficient $\left(\mathrm{R}^{2}\right)$ at $25^{\circ} \mathrm{C}$ could be calculated
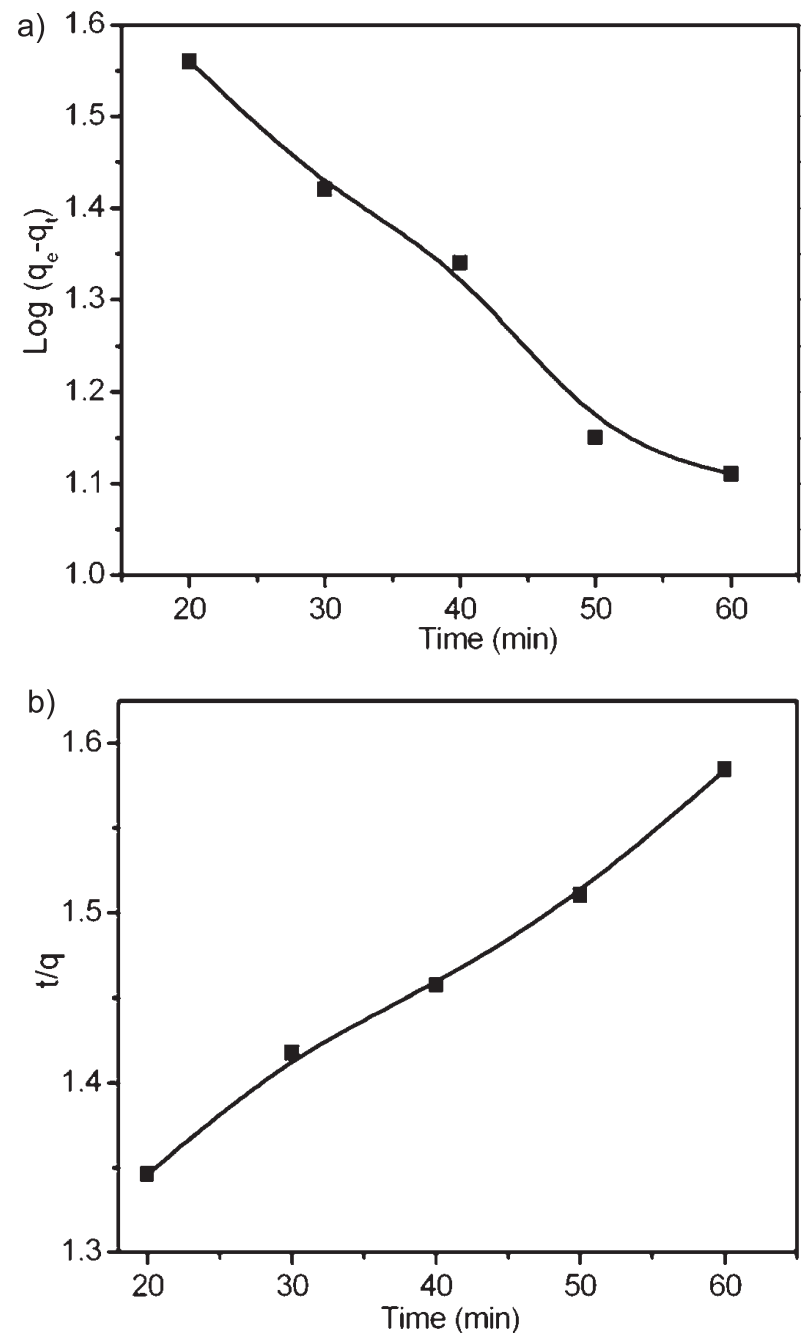

Fig. 8. Pseudo a) first-order kinetic, b) second-order kinetic of sorption thallium on pseudomonas (m: $0.1 \mathrm{~g}, \mathrm{~V}: 100 \mathrm{~mL}, \mathrm{Tl}$ : $50 \mu \mathrm{g} / \mathrm{mL}, \mathrm{pH}: 5.0)$.

Table 1. Langmuir and Freundlich biosorption isotherm constants for Thallium Pseudomonas fluorescens biosorbents.

\begin{tabular}{|c|c|c|c|c|c|}
\hline \multicolumn{3}{|c|}{ Langmuir model } & \multicolumn{3}{c|}{ Freunclich model } \\
\hline $\begin{array}{c}\mathrm{q}_{\max } \\
(\mathrm{mg} / \mathrm{g})\end{array}$ & $\mathrm{b}(\mathrm{l} / \mathrm{g})$ & $\mathrm{R}^{2}$ & $\mathrm{~K}_{\mathrm{f}}$ & $\mathrm{n}$ & $\mathrm{R}^{2}$ \\
\hline 93.76 & 0.0275 & 0.9967 & 6.9231 & 1.9214 & 0.9166 \\
\hline
\end{tabular}

Table 2. Parameters of the pseudo first- and second-order kinetic models for the biosorption of Thallium on Pseudomonas fluorescens.

\begin{tabular}{|c|c|c|c|c|c|}
\hline \multicolumn{3}{|c|}{$\begin{array}{c}\text { Pdeudo first-order kinetic } \\
\text { model }\end{array}$} & \multicolumn{3}{|c|}{$\begin{array}{c}\text { Pdeudo second-order kinetic } \\
\text { model }\end{array}$} \\
\hline $\begin{array}{c}\mathrm{Q}_{1} \\
(\mathrm{mg} / \mathrm{g})\end{array}$ & $\begin{array}{c}\mathrm{K}_{1} \\
\left(\mathrm{~min}^{-1}\right)\end{array}$ & $\mathrm{R}^{2}$ & $\begin{array}{c}\mathrm{q} \\
(\mathrm{mg} / \mathrm{g})\end{array}$ & $\begin{array}{c}\mathrm{K}_{2} \\
\left(\mathrm{gmg}^{-1} \mathrm{~min}^{-1}\right)\end{array}$ & $\mathrm{R}^{2}$ \\
\hline 93.76 & 0.2336 & 0.9892 & 43.64 & 0.00081618 & 0.9950 \\
\hline
\end{tabular}

through the slope and intercept of the fitted linear equation (Table 1). It can be seen that the correlation coefficients $\left(\mathrm{R}^{2}=0.995\right)$ for the pseudo second-order was higher than that of pseudo first-order, which could be used to deduce that the pseudo second-order kinetic model can better describe the adsorption of Tl(I) by the strain Pseudomonas fluorescens than the pseudo first-order one.

\section{Conclusions}

The results obtained demonstrate that dead cells have the ability to uptake quantities of thallium. The maximum adsorption capacity of thallium by dead biomass was $93.76 \mathrm{mg} / \mathrm{g}$ with an initial $\mathrm{Tl}(\mathrm{I})$ ion concentration of $50 \mathrm{mg} / \mathrm{L}$ at $\mathrm{pH} 5$ and $25^{\circ} \mathrm{C}$. The batch adsorption isotherm can to be described using the Langmuir isotherm and Freundlich model. The equilibrium process fit the Langmuir model well, suggesting that monolayer adsorption is stronger than the heterogeneous adsorption for this process. Kinetic analysis shows that much higher $\mathrm{R}^{2}$-values and a more accurate value of $\mathrm{q}_{\mathrm{e}}$ for the pseudo second-order than for the pseudo first-order one.

The mechanism of adsorption includes mainly ion exchange and generation of complexes between heavy metal ions and binding sites onto the cell wall. The results of FT-IR spectrum analysis confirmed the existence of carboxyl, hydroxyl, and amino groups in the biomass of Pseudomonas fluorescens and their possible participation in $\mathrm{Tl}(\mathrm{I})$ ion adsorption. These show that the strain of Pseudomonas fluorescens may be a potential and lowcost biosorbent for the removal of $\mathrm{Tl}(\mathrm{I})$ ion form aqueous solutions.

\section{Acknowledgements}

We gratefully acknowledge the financial support provided by National Natural Science Foundation of China (Nos. U1501231, 41573119, 41376156, 41372248, and 41273100), the Science and Technology Plan of Guangzhou (Nos. 201510010204 and 201607010286), the Public Welfare Scientific Fund of the Environmental Protection Department (No. 201509051), the Provincial Natural Science Foundation of Guangdong (No. S2013010016540), and a high-level university construction project (regional water environment safety and water ecological protection). 


\section{References}

1. HIRAK R., DASH SURAJIT DAS. Bioremediation of inorganic mercury through volatilization and biosorption by transgenic Bacillus cereus BW-03 (pW-05). Int Biodeter Biodegr. 103, 179, 2015.

2. MULKEY J.P.,OEHME F.W. A review of thallium toxicity. Vet Hum Toxicol. 35 (6), 445, 1993.

3. A.L. JOHN PETER., VIRARAGHAVAN T. Removal of thallium from aqueous solutions by modified Aspergillus niger biomass. Bioresour. Technol. 99 (3), 618, 2008.

4. ZEYNEP MINE SENOL, ULVI ULUSOY. Thallium adsorption onto polyacryamide-aluminosilicate composites: A TI istope tracer study. Chem. Eng.J. 162 (1), 97, 2010.

5. GUANGMING REN., YU JIN., CHUNMIAO ZHANG., HAIDONG GU., JUANJUAN QU. Characteristics of Bacillus sp. PZ-1 and its biosorption to $\mathrm{Pb}$ (II). Ecotox environ safe. 117 (4), 141, 2015.

6. XIAOYAN LIN., RENXIANG MOU., ZHAOYUN CAO., PING XU., XIAOLIANG WU., ZHIWEI ZHU., MINGXUE CHEN. Characterization of cadmium-resistant bacteria and their potential for reducing accumulation of cadmium in rice grains. Sci Total Environ. 569-570 (11), 97, 2016.

7. DEEPAK GOLA., PRIYADAR SHINIDEY., ARGHYA BHATTACHARYA., ABHISHEK MISHRA., ANUSHREEMALIK, MANEESHNAMBURATH., SHAIKHZIAUDDINAHAMMAD. Multiple heavy metal removal using an entomopathogenic fungi Beauveria bassiana. Bioresour. Technol. 218, 388, 2016.

8. JIAN HUANG., DONGFANG LIU., JIANBO LU., HAO WANG., XIAOCHENG WEI., JINZHE LIU. Biosorption of reactive black 5 by modified Aspergillus versicolor biomass: Kinetics, capacity and mechanism studies. Colloids and Surfaces A: Physicochem. Eng. Aspects. 492, 242, 2016.

9. VANESSA R.A. FERREIRA., CATARINA L. AMORIM., SARA M. CRAVO., MARIA E. TIRITAN., PAULA M.L. CASTRO., CARLOS M.M. AFONSO. Fluoroquinolones biosorption onto microbial biomass: activated sludge and aerobic granular sludge. Int Biodeter Biodegr. 110 (3), 53, 2016.

10. REZA TABARAKI., SALMAN AHMADY-ASBCHIN., OMRAN ABDI. Biosorption of $\mathrm{Zn}$ (II) from aqueous by Acinetobacter sp. Isolated from petroleum spilled soil. J. Environ. Chem. Eng. 1, 604, 2013.

11. ATAC UZEL., GUVEN OZDEMIR. Metal biosorption capacity of the organic solvent tolerant Pseudomonas fluorescens TEM08. Bioresour. Technol. 100 (7), 542, 2009.

12. KSHAMA A. SHROFF., VARSHA K. VAIDYA. Kinetics and equilibrium studies on biosorption of nickel from aqueous solution by dead fungal biomass of Mucor hiemalis. Chem. Eng. J. 171, 1234, 2011.

13. HASSIMI ABU HASAN., SITIROZAIMAH SHEIKH ABDULLAH., NOORHISHAM TAN KOFLI., SHY JAY YEOH. Interaction of environmental factors on simultaneous biosorption of lead and manganese ions by locally isolated Bacillus cereus. J Ind Eng Chem. 37, 295, 2016.

14. SAEED UR REHMAN., NAJEEB ULLAH., ALI REZA KAMALI., KHURSHID ALI., CEMILE YERLIKAYA.,HANIF UR REHMAN. Study of thallium (III) adsorption onto multiwall carbon nanotubes. New Carbon Mater . 27 (6), 409, 2012.

15. RAJESWARI.M. KULKARNI., K. VIDYA SHETTY., G. SRINIKETHAN. Cadmium (II) and nickel (II) biosorption by Bacillus laterosporus (MTCC 1628). J Taiwan Inst Chem. 45, 1628, 2014.
16. SINHA S., MUKHERJEE S.K. Cadmium-induced siderophore production by a highly Cd-resistant bacterial strain relieved $\mathrm{Cd}$ toxicity in plants through root colonization. Curr. Microbiol. 56, 55, 2008.

17. CHOI J., LEE J.Y., YANG J.S. Biosorption of heavy metals and uranium by starfish and Pseudomonas putida, J. Hazard. Mater. 161, 157, 2009.

18. SELATNIAA., BOUKAZOULAA., KECHID N., BAKHTI M.Z., CHERGUI A., KERCHICH Y. Biosorption of lead (II) from aqueous solution by a bacterial dead Streptomyces rimosus biomass. Biochem Eng J. 19 (2), 127, 2004.

19. BULGARIU D., BULGARIU L. Equilibrium and kinetics studies of heavy metal ions biosorption on green algae waste biomass. Bioresour. Technol. 103, 489, 2012.

20. LANGMUIR I. The adsorption of gases on plane surfaces of glass, mica and platinum. J Am Chem. Soc. 40, 1361, 1918.

21. FREUNDLICH H., HELLE W. On adsorption in solution. J Am Chem. Soc. 61 (2), 28, 1939.

22. DIEGO M. VENEU., MAURICIO L. T., GABRIELA A.H. PINO. Fundamental aspects of copper and zinc removal from aqueous solutions using a Streptomyces lunalinharesii strain. Miner Eng. 48 (2), 44, 2013.

23. PERUMAL VENKATESH., MELEPPAT BALRAJ., REPALLY AYYANNA., DASARI ANKAIAH., VENKATESAN ARUL. Physicochemical and biosorption properties of novel exopolysaccharide produced by Enterococcus faecalis. Lwt-Food Sci Technol. 68 (5), 606, 2016.

24. HOZHABR SOHBATZADEH., ALI REZA KESHTKAR., JABERSAFDARI., FAEZEH FATEMI. U(VI) biosorption by bi-functionalized Pseudomonas putida@ chitosanbead: Modeling and optimization using RSM. Int J Biol Macromol. 89 (8), 647, 2016.

25. ERTUGAY N., BAYHAN Y.K. Biosorption of $\mathrm{Cr}$ (VI) from aqueous solutions by biomass of Agaricus bisporus. $\mathrm{J}$ Hazard Mater. 154 (10), 432, 2008.

26. JIN-HO JOO., SEDKY H.A. HASSAN., SANG-EUN OH. Comparative study of biosorption of $\mathrm{Zn}^{2+}$ by Pseudomonas aeruginosa and Bacillus cereus. Int Biodeter Biodegr. 64 (9), 734, 2010.

27. SADINOZDEMIR., ERSINKILINC., ANNARITAPOLI., BARBARA NICOLAUS, KEMAL GUVEN. Biosorption of $\mathrm{Cd}, \mathrm{Cu}, \mathrm{Ni}, \mathrm{Mn}$ and $\mathrm{Zn}$ from aqueous solutions by thermophilic bacteria, Geobacillus toebiisub.sp. decanicus and Geobacillus thermoleovorans sub.sp. stromboliensis: Equilibrium, kinetic and thermodynamic studies. Chem. Eng. J. 152, 195, 2009.

28. PANG C., LIU Y., CAO X., LI M., HUANG G., HUA R., WANG C., LIU Y., AN X. Biosorption of uranium (VI) from aqueous solution by dead fungal biomass of Penicillium citrinum. Chem. Eng. J. 170 (1), 1, 2011.

29. DIEGO M. VENEU., GABRIELAA.H. PINO., MAURICIO L. TOREM., TATIANA D., SAINT'PIERRE. Biosorptive removal of cadmium from aqueous solutions using a Streptomyces lunalinharesii strain. Miner Eng. 29, 112, 2012.

30. GM FIGUEROA-TORRES., MT CERTUCHABARRAGÁN., EACEDO-FÉLIX., O MONGE-AMAYA.,FJ ALMENDARIZ TAPIA. Kinetic studies of heavy metals biosorption by acidogenic biomass immobilized in clinoptilolite. J Taiwan Inst Chem. 61, 241, 2016.

31. NASRIN MASOUDZADEH., FARDIDEH ZAKERI., TAYEBE BAGHERI LOTFABAD., HAKIMEH SHARAFI., FATEMEH MASOOMI., HOSEEIN SHAHBANI ZAHIRI., GHOLAMREZA AHMADIAN., KAMBIZ AKBARI NOGHABI. Biosorption of cadmium by Brevundimonas 
sp. ZF12 strain, a novel biosorbent isolated from hotspring waters in high background radiation areas. J Hazard Mater.197, 190, 2011.

32. SHWETA SARASWAT., J.P.N.RAI. Complexation and detoxification of $\mathrm{Zn}$ and $\mathrm{Cd}$ in metal accumulation plants. Rev environ Sci Biotechnol. 10 (4), 327, 2011.

33. RM PÉREZ SILVA. Biosorption of chromium, copper, manganese and zinc by Pseudomonas aeruginosa AT18 isolated from a site contaminated with petroleum. Bioresour. Technol. 100 (4), 1533, 2008.
34. ANINDITA BANERJEE., PRIYABRATA SARKAR. SUCHETANA BANERJEE. Application of statistical design of experiments for optimization of $\mathrm{As}(\mathrm{V})$ biosorption by immobilized bacterial biomass. Ecol Eng. 86, 13, 2016.

35. LAGERGREN S. About the theory of so-called adsorption of soluble substances. K Sven Vetenskapsakad Handl. 24, 1, 1898.

36. HO Y.S., MCKAY G. Pseudo-second order model for sorption processes. Process Biochem. 34, 451, 1999. 